\title{
Biomedical research: US looks to a mixed economy
}

\section{David Dickson describes moves to put medical research planning on to a multi-year basis}

The Shock-Waves of California's decision to slash its property taxes were felt in Washington last week when the House of Representatives made a $2 \%$ cut of $\$ 800$ million from the budget request of the Department of Health, Education and Welfare.

The House has left it to the administration to decide where the cuts-if they are not restored by action in the Senate-should fall. This has brought to a head debate within the department over how its increasingly-restricted budget should be distributed between its various responsibilities, including the support of biomedical research.

The department's role in supporting basic science had already been put under scrutiny by HEW Secretary Joseph Califano, following President Carter's budget statement which emphasised the need to redress the federal government's comparative neglect of basic research in recent years.

Largely in response to the executive branch's initiative-although also reflecting concerns expressed by scientists themselves that too much stress has recently been placed on short-term, targeted research-Dr Califano is now proposing to draw up a five-year programme for health services research.

Outlining his proposal to a recent meeting of the American Federation for Clinical Research in San Francisco, $\mathrm{Mr}$ Califano said that limitations on resources for basic research made it necessary to develop a better strategy of allocation. "A multi-year plan will serve to level out the annual appropriations fluctuations that make rational research planning so difficult", he said.

$\mathrm{Mr}$ Califano said there was a need for an "across the board" strategy for health research that assessed research and health needs in a systematic and comprehensive way. $\mathrm{He}$ hoped to publish a multi-year plan-probably for five years - in early 1980, preceded by wide discussion about the principles on which such a plan should be based.

Among the principles offered by $\mathrm{Mr}$ Califano himself were: the need to respect a scientist's freedom to pursue research topics not immediately relevant to social needs; adequate support for population-based life sciences such as epidemiology and biostatistics; ample research opportunities for young investigators; and the strong orientation of government-supported research towards improving the quality of health services.

The task of putting flesh on these principles, and of establishing the framework of the national debate scheduled to take place over the next few months, has been given to $\mathrm{Dr}$ Donald Fredrickson, director of the National Institute of Health which was responsible for $\$ 2.2$ billion out of the $\$ 2.6$ billion spent by HEW in 1977 on research and development.

Dr Fredrickson is keen to maintain a coherent research spectrum, ranging from the basic biological and biomedical sciences at one end to the more "targeted" problems of health care at the other. "Don't try to Rothschild it all", he told an open meeting of his advisory committee at NIH last week, referring to the British government's attempts to transfer responsibility for applied medical research from the Medical Research Council to the Department of Health and Social Security.

However, in attempting to map out a strategy for biomedical research that fits into Mr Califano's overall objectives, Dr Fredrickson faces a major dilemma: how to combine the essentially quality control forms of guidance required by one type of research with the more direct forms of intervention and control appropriate to the other.

"My major concern is to find how close you can bring the scientific process to other missions of the department of a more regulatory or service nature. But our problem is keeping out of some of the entanglements involved in these latter areas, while meeting our social responsibilities as biomedical scientists", Dr Fredrickson said.

Many scientists welcome the stability that a multi-year strategy could give to research. Particular areas in which it is felt such a strategy could help are in the supply and maintenance of equipment, and in providing measures to ensure the continued recruitment of young scientists into a field where career opportunities are decreasing daily.

Some members of the advisory committee, however, were concerned at last week's meeting that, by concentrating on applied health research, NIH might be threatening the support of nontargeted areas, especially if there was no overall budget increase.

Others expressed a general wariness of attempts to apply a planning strategy to basic science. Dr George Palade, chairman of the cell biology section of Yale University Medical School, echoed a common sentiment when he said it was impossible to predict the

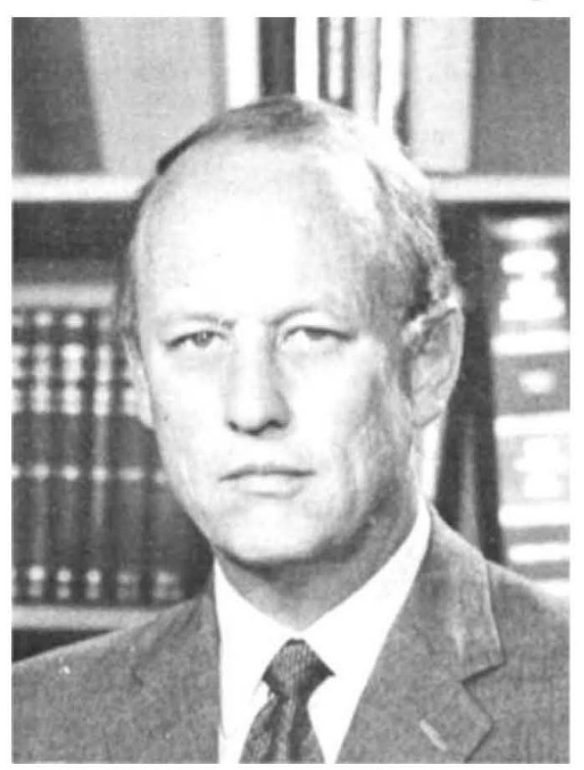

Fredrickson: "Don't try to Rothschild it all"

fields from which critical contributions to the solution of biomedical problems were to come and so, it was impossible to plan research in a rational way.

Yet despite growing acceptance in political circles that the "disease of the month" approach to medical research so popular in the early 1970 s has succeeded only in frustrating public expectations, Congress is far from accepting that its best strategy should be to give scientists the money and let them choose how to spend it.

Politicians and scientists, for example, now frequently engage in mutual recrimination for the apparent failure of the "war against cancer" to come up with promised results. Perhaps more seriously, there is also growing concern about the back up which scientists do, or do not, provide to regulatory agencies such as the Environmental Protection Agency and the Food and Drug Administration.

On the one hand, academic scientists tend to claim it is unrealistic for such agencies to approach them with specific requests, such as better short-term carcinogen tests, before a full understanding has been achieved of the biological processes involved. On the other hand, the agencies themselves, faced with the need to make decisions based on inadequate data, complain that they are often cold-shouldered by the scientific community, and that their own scientific efforts suffer as a result.

Such are the issues with which Dr Fredrickson now has to do battle. Several of those at last week's meeting suggested that an appropriate strategy to present to $\mathrm{Mr}$ Califano was one that 
would guarantee a certain level of support for the "science base" of NIH's activities, leaving research issues more related to health care to be discussed within the broader framework of HEW priorities.

Dr Fredrickson has indicated that he personally favours such a "mixed economy" approach to research planning. "I do not believe in the rational plan- ning of science beyond a very limited range", he told the meeting. But just how limited that range is-or should be-is likely to be the subject of heated debate in the months ahead.

\section{Canada announces major research boost}

The Canadran Government has announced a package of measures designed to stimulate research and development activities, the low level of support for which has recently been the target of widespread public criticism. The Government's declared intention is to raise the proportion of the nation's gross national product spent on $\mathrm{R} \& \mathrm{D}$ from $0.9 \%$ to $1.4 \%$ over the next five years.

Included in the package is an increase of $\$ 5.35$ million in the budget of the National Research Council to enable it to expand its programmes and establish university-based research centres. This should improve cooperation between Government, research and industry.

The plan also allows for an immediate increase of $\$ 10 \mathrm{~m}$ in the budgets of the three main grant-giving bodies over and above the budgets already announced for 1978-79. As a result, the budget of the newly-formed Natural Sciences and Engineering Council will increase by $12.4 \%$ to $\$ 109.8 \mathrm{~m}$ (rather than increasing by only $7.1 \%$, as originally planned). Similarly the budget of the Medical Research Council will increase by $11.1 \%$ (rather than $5.8 \%$ ), to $\$ 63 \mathrm{~m}$, and that of the Social Science and Humanities Research Council will increase by $15 \%$ (rather than $7.8 \%$ ) to $\$ 33.1 \mathrm{~m}$.

In April, the Medical Research Council announced that, with only a $5.8 \%$ increase in funds budgeted for next year, it was having to terminate a fifth of its established research projects, and would only be able to fund $30 \%$ of the grant applications which it had received and had judged worthy of support. The new money, whose distribution will be at the discretion of the council, means that such drastic cuts are no longer necessary.

Following a meeting of the council at the end of last week, a spokesman said that the increase would allow the council to continue to fund projects of national importance without having to cut into its research base.

In slight contrast to the MRC, both of the other research councils have been told that the extra money should be spent on research projects which are seen to be of national importance. This reflects the main goal of the Government's package, which is to increase the technological strength of Canadian industry.

Thus, in addition to the extra money given to the grant-issuing bodies, $\mathrm{Mr}$ Buchanan also announced that the Government would increase its contracting-out research programme in each of the next two years, and would spend $\$ 6.8 \mathrm{~m}$ to establish research centres to assist in the development of industrial research activities.

Furthermore the Government is planning to introduce a $\$ 3 \mathrm{~m}$ works programme to create jobs for scientists and technicians to undertake research projects at the request of industrial firms.

The long-term need for a major basic research effort to support a national technological development programme was also emphasised last week by Dr Josef Kates, chairman of the Science Council of Canada. In a statement published with the council's annual report, Dr Kates says that Canada's previous emphasis on technology transfer has not allowed it to participate effectively in R \& D efforts leading to successful innovations and developments.

Stressing the Science Council's demand for a policy of "technological sovereignty" as a strategy for achieving scientific, industrial and economic strength, Dr Kates said that part of this policy should include an ability to barter competently and toughly for technologies which could be used to enhance Canada's industrial base.

"Unfortunately, many of the scientific agreements negotiated between Canada and other countries seem to reflect a sense of diplomatic exchange rather than of genuine technology transfer", Dr Kates says.

Other members of the scientific community, however, while welcoming the Government's decision to increase funds for R \& D, are concerned at the apparent emphasis on targeted research. They feel that, in the longterm, support for basic research is necessary to guarantee the success of targeted research.

"We are worried that the result of this emphasis may be to leave many university scientists out in the cold. Furthermore, if industry fails to make good use of the incentives it is being offered by the Government, this could ultimately damage support for research in other sectors", Dr John Kucharcyzk, of the Canadian Federation of Biological Sciences, said last week.

David Dickson

\section{Computer secrecy ban lifted}

Following widespread criticism of apparent attempts to infringe academic freedom, the US Department of Commerce announced last week that it had decided to lift a secrecy ban imposed on 21 April on a research scientist at the University of Wisconsin-Milwaukee who has been working on the security of computer-based data systems.

According to a Department spokesman, the ban-which was imposed when the research scientist, Dr George Davida, had applied for a patent for techniques arising from his unclassified research-had originally been re- quested by the Department of Defense. It was withdrawn following an inquiry by Commerce Department officials. $\square$

\section{Fall in graduate enrolment}

The Number of graduate students enrolled in science programmes in US educational institutions fell by $1 \%$ in 1977, following continual growth since 1973, according to figures released last week by the National Science Foundation.

A $2 \%$ increase in part-time enrolment to 113,700 was more than offset by a $2 \%$ decrease in full-time numbers to 228,600 , leading to a total decrease of 3,400 between the fall of 1976 and the fall of 1977-from 345,700 and 342,300 .

Improved job opportunities for those without a PhD was one of the main reasons for the decrease, according to the NSF.

Other possible causes included a $35 \%$ reduction in the enrolment of war veterans because GI Bill benefits have expired, increasing tuition and living costs, and declining federal support to students in graduate science and engineering programmes. 